\title{
Ergosterol isolated from the basidiomycete Pleurotus salmoneostramineus affects Trypanosoma cruzi plasma membrane and mitochondria
}

Tatiana Rodrigues Alexandre ${ }^{1}$, Marta Lopes Lima ${ }^{1,2}$, Mariana Kolos Galuppo ${ }^{1}$, Juliana Tonini Mesquita', Matilia Ana do Nascimento ${ }^{1}$, Augusto Leonardo dos Santos ${ }^{3}$, Patricia Sartorelli ${ }^{3}$, Daniel Carvalho Pimenta ${ }^{4}$ and Andre Gustavo Tempone ${ }^{1 *}$

\begin{abstract}
Background: Major drawbacks of the available treatment against Chagas disease (American trypanosomiasis) include its toxicity and therapeutic inefficiency in the chronic phase of the infection, which makes it a concern among neglected diseases. Therefore, the discovery of alternative drugs for treating chronic Chagas disease requires immediate action. In this work, we evaluated the mushroom Pleurotus salmoneostramineus in the search for potential antiparasitic compounds.

Methods: Fruit bodies of the basidiomycete Pleurotus salmoneostramineus were triturated and submitted to organic solvent extraction. After liquid-liquid partition of the crude extract, three fractions were obtained and the bioguided fractionation study was conducted to isolate the active metabolites. The elucidation of the chemical structure was performed using GC-MS and NMR techniques. The biological assays for antiparasitic activity were carried out using trypomastigotes of Trypanosoma cruzi and murine macrophages for mammalian cytotoxicity. The mechanism of action of the isolated compound used different fluorescent probes to evaluate the plasma membrane permeability, the potential of the mitochondrial membrane and the intracellular levels of reactive oxygen species (ROS).

Results: The most abundant fraction showing the antiparasitic activity was isolated and chemically elucidated, confirming the presence of ergosterol. It showed anti-Trypanosoma cruzi activity against trypomastigotes, with an $I_{50}$ value of $51.3 \mu \mathrm{g} / \mathrm{mL}$. The compound demonstrated no cytotoxicity against mammalian cells to the maximal tested concentration of $200 \mu \mathrm{g} / \mathrm{mL}$. The mechanism of action of ergosterol in Trypanosoma cruzi trypomastigotes resulted in permeabilization of the plasma membrane, as well as depolarization of mitochondrial membrane potential, leading to parasite death. Nevertheless, no increase in ROS levels could be observed, suggesting damages to plasma membrane rather than an induction of oxidative stress in the parasite.
\end{abstract}

Conclusions: The selection of naturally antiparasitic secondary metabolites in basidiomycetes, such as ergosterol, may provide potential scaffolds for drug design studies against neglected diseases.

Keywords: Pleurotus salmoneostramineus, Ergosterol, Trypanosoma cruzi, Mechanism of action

\footnotetext{
* Correspondence: atempone@usp.br

${ }^{1}$ Center for Parasitology and Mycology, Instituto Adolfo Lutz, Avenida Dr.

Arnaldo, 351, $8^{\circ}$ andar, CEP 01246-000, São Paulo, SP, Brazil

Full list of author information is available at the end of the article
} 


\section{Background}

Chagas disease (CD) was described in 1909 by the Brazilian researcher Carlos Ribeiro Justiniano das Chagas [1]. It is currently estimated that 8 million people are infected worldwide, especially in 21 countries of Latin America. CD is responsible for 10,000 deaths annually, being a risk for 100 million people [2]. In Brazil, prevalent chronic cases of $\mathrm{CD}$ result from infections acquired in the past, affecting approximately three million individuals $[2,3]$. However, in recent years, the occurrence of acute Chagas disease (ACD) has been observed in the Amazon, with the manifestation of isolated cases in other states [4]. Trypanosoma cruzi is the etiologic agent of CD, a hemoflagellate protozoan from the Kinetoplastida order [5]. Although CD has been described more than 100 years ago, the chemotherapy is, so far, limited to two nitro-heterocyclic drugs: benznidazole and nifurtimox [6]. Both are effective in the acute phase of the infection, with approximately $60-80 \%$ efficacy [7]. However, they are considered far from ideal in the chronic phase of the disease, with severe adverse effects and reduced efficacy $[7,8]$.

Due to this toxic and limited therapeutic arsenal, there is an urgent need to find new drugs. Considering that natural products have been providing interesting scaffolds for protozoan diseases, herein we investigated the potential of basidiomycetes, a rich source for antimicrobial compounds. For example, hypnofylline and panepoxidone isolated from the basidiomycete Lentinus strigosus and an ergosterol peroxide isolated from Pleurotus ostreatus have demonstrated anti-T. cruzi activities $[9,10]$. Considering the genus Pleurotus, a number of secondary metabolites have been isolated with different biological properties, such as antitumor, antileishmanial, antimicrobial, anti-inflammatory and antitrypanosomal activities among others [10-14].

To the best of our knowledge, this is the first study that identified the antiparasitic potential of Pleurotus salmoneostramineus - popularly known as the "pink mushroom" - that grows on leaves of senescent plants found in Japan, New Guinea and Siberia. It is a popular mushroom because of the colorful body, flavor and texture, being rich in proteins, lipids, fiber, carbohydrates, vitamins and essential amino acids. It is generally used in reducing plasma cholesterol levels and prevents atherosclerosis $[15,16]$. By using the bioguided fractionation, we isolated and chemically characterized the most abundant metabolite of $P$. salmoneostramineus with antitrypanosomal activity and evaluated its action on the plasma membrane, mitochondria and ROS levels of trypomastigote forms of the parasite.

\section{Methods}

\section{Basidiomycete and chemicals}

The basidiomycete Pleurotus salmoneostramineus was commercially purchased from Zucca Funzionale (Brazil) and its identification was confirmed by the Adolfo Lutz Institute. Phosphate-buffered saline (PBS), Roswell Park Memorial Institute Medium (RPMI 1640), Hank's Balanced Salt Solution (HBSS), sodium azide, Triton X-100, carbonyl cyanide 4-(trifluoromethoxy)phenylhydrazone (FCCP), miltefosine, benznidazole (2-nitroimidazole), and the solvents dimethyl sulfoxide (DMSO), methanol $(\mathrm{MeOH})$, hexane, ethyl acetate (EtOAc), butanol and dichloromethane were purchased from Sigma. The TLC Siligel 60 F254 aluminum chromatoplates with fluorescence indicators and common silica were purchased from Merk. Resazurin, sodium dodecyl sulfate (SDS), Sytox Green dye, Mitotracker Red CM-H2XROS, $\mathrm{H}_{2}$ DCf-DA and MTT were purchased from Molecular Probes $^{\oplus}$ (Invitrogen).

\section{Parasites, mammalian cells and experimental animals} Trypomastigotes of Trypanossoma cruzi (Y strain) were maintained in LLC-MK2 (ATCC CCL 7) cells using RPMI-1640 medium supplemented with $2 \%$ fetal bovine serum (FBS) at $37{ }^{\circ} \mathrm{C}$ in $5 \% \mathrm{CO}_{2}$ humidified incubator. LLC-MK2 (ATCC) cells were maintained in RPMI-1640 medium without phenol red and supplemented with $10 \%$ SBF at the same conditions [17]. Peritoneal macrophages were collected from the peritoneal cavity of female BALB/c mice by washing with RPMI-1640 without phenol red, supplemented with $10 \% \mathrm{FBS}$. BALB/c mice were supplied by the animal breeding facility at the Adolfo Lutz Institute and maintained in sterilized cages under a controlled environment, receiving water and food ad libitum. Animal procedures were performed with the approval of the Research Ethics Commission (CEUA-IAL-Pasteur 01/2011), in agreement with the Guide for the Care and Use of Laboratory Animals from the National Academy of Sciences.

\section{Crude extract and liquid-liquid partition}

Fruit-bodies of mushrooms basidiomycete $P$. salmoneostramineus (1000 g) were triturated and extracted with 1.4 L MeOH: $\mathrm{H}_{2} \mathrm{O}$ solution (1:1 v/v). This solution was sonicated (10 $\mathrm{min})$, filtered (Whatman filter) and evaporated at $40{ }^{\circ} \mathrm{C}$ resulting in the crude extract. Subsequently, the crude extract was resuspended in $400 \mathrm{~mL}$ of water and partitioned using growing polarity solvents to afford the three fractions, n-hexane $(518.8 \mathrm{mg})$, EtOAc (3432.9 $\mathrm{mg}$ ) and butanol (1923.2 $\mathrm{mg}$ ). Then, these fractions were dried at $40{ }^{\circ} \mathrm{C}$ and stored at $-20{ }^{\circ} \mathrm{C}$ until analysis.

\section{Determination of $50 \%$ inhibitory concentration $\left(\mathrm{IC}_{50}\right)$ against Trypanosoma cruzi}

To determine the $50 \%$ inhibitory concentration $\left(\mathrm{IC}_{50}\right)$ against free trypomastigotes of $T$. cruzi obtained from LLC-MK2 cultures, $1 \times 10^{6}$ parasites/well were seeded 
on 96-well microplates. N-hexane, EtOAc and butanol fractions were dissolved in $\mathrm{MeOH}$, serially diluted (twofold) in RPMI-1640 medium and incubated with the parasites in a range concentration between 300 and $2.3 \mu \mathrm{g} /$ $\mathrm{mL}$ (final volume $200 \mu \mathrm{L}$ ) for $24 \mathrm{~h}, 37{ }^{\circ} \mathrm{C}, 5 \% \mathrm{CO}_{2}$. At the same conditions, the isolated compound was dissolved in DMSO, serially diluted (two-fold) and added to the highest concentration of $150 \mu \mathrm{g} / \mathrm{mL}$. Benznidazole was used as a standard drug in a range concentration between 100 and $0.78 \mu \mathrm{g} / \mathrm{mL}$. The parasite viability was determined by resazurin assay $(0.11 \mathrm{mg} / \mathrm{mL}$ in PBS, $20 \mathrm{~h}$ incubation) using the FilterMax F5 Multi-Mode Microplate Reader, Molecular Devices (Sunnyvale, CA, USA), at $570 \mathrm{~nm}$ [18]. DMSO was used to dissolve the compounds and was included in the microplate at $0.5 \%(\mathrm{v} / \mathrm{v})$ to avoid toxicity. Internal controls were also performed with DMSO. Additionally, the lethal effect of the isolated compound was confirmed on trypomastigotes using classical light microscopy analysis [19].

To determine the $\mathrm{IC}_{50}$ against intracellular amastigotes of $T$. cruzi, peritoneal macrophages were dispensed in 16-well chamber slide (NUNC, Thermo, USA) and maintained for $24 \mathrm{~h}$ in the same medium at $37{ }^{\circ} \mathrm{C}$ in a $5 \% \mathrm{CO}_{2}$ humidified incubator for attachment. Non adherent cells were removed by two-step washings with medium. After $24 \mathrm{~h}$, these cells were infected with $1 \times$ $10^{6}$ culture trypomastigotes forms for $4 \mathrm{~h}$. Subsequently, infected cells were incubated with the ergosterol in a range concentration between 100 and $0.78 \mu \mathrm{g} / \mathrm{mL}$ (final volume $200 \mu \mathrm{L}$ ) for $48 \mathrm{~h}$. Finally, the slides were fixed with methanol, stained with Giemsa, and observed in a light microscope. The parasite load was defined by counting 400 macrophages/well by evaluating the number of infected macrophages. Benznidazole was used as standard drug in a range concentration between 50 and $0.39 \mu \mathrm{g} / \mathrm{mL}$. DMSO was used at a maximal concentration of $0.5 \%(\mathrm{v} / \mathrm{v})$ and incubated with cells as an internal control [20].

\section{Bioguided fractionation}

The anti-trypomastigote activity guided the fractionation procedures. $n$-hexane, EtOAc and butanol fractions were subjected to thin layer chromatography (TLC) in aluminum plates of silica gel $60 \mathrm{~F}_{254}$ TLC with a fluorescent indicator at $254 \mathrm{~nm} .{ }^{1} \mathrm{H}$ and ${ }^{13} \mathrm{C}$ RMN analysis, with spectra recorded at 300 and $75 \mathrm{MHz}$, were performed using a Bruker Ultrashield 300 Avance III spectrometer, respectively. $\mathrm{CDCl} 3$ (Aldrich) was used as the solvent with TMS as the internal standard. Chemical shifts $(\delta)$ are reported in ppm and the coupling constant (J) in Hz. $n$-hexane fraction were subjected to column chromatography (CC) with $89 \mathrm{~g}$ of silica gel G-60 (Merk, 0.063-0.200 $\mathrm{mm}$ ) and $510 \mathrm{mg} \mathrm{n}$-hexane fraction (CPS column Pleurotus salmoneostramineus). Solvent system started with pure $n$-hexane $(10: 0, \mathrm{v} / \mathrm{v})$ to pure EtOAc $(0: 10, \mathrm{v} / \mathrm{v}, 50 \mathrm{~mL})$, followed by increasing amounts of $\mathrm{MeOH}$ (EtOAc 9:1, v/v to pure $\mathrm{MeOH} 0: 10, \mathrm{v} / \mathrm{v}$ ). New fractions obtained from this process $(50 \mathrm{~mL})$ were dried at $40{ }^{\circ} \mathrm{C}$ and stored at $-20{ }^{\circ} \mathrm{C}$ until analysis. Structural elucidation of fraction CPS-3(3) were performed by analysis ${ }^{1} \mathrm{H}$ and ${ }^{13} \mathrm{C}$ RMN and GC-MS.

\section{Cytotoxicity against mammalian cells}

To determine the $50 \%$ cytotoxic concentration $\left(\mathrm{CC}_{50}\right)$ of the isolated compound, it was previously dissolved in DMSO, serially diluted (two-fold) in RPMI-1640 medium-10\% SBF at maximum concentration of $200 \mu \mathrm{g} /$ $\mathrm{mL}$ and incubated with $6 \times 10^{4}$ peritoneal macrophages seeded on 96-well microplates, final volume of $200 \mu \mathrm{L}$ during $48 \mathrm{~h}, 37^{\circ} \mathrm{C} 5 \% \mathrm{CO}_{2}$. Cell viability was determined by resazurin assay as above described. Same conditions were applied to determine the $\mathrm{CC}_{50}$ of the standard drug benznidazole, which was tested in a range concentration between 200 and $1.56 \mu \mathrm{g} / \mathrm{mL}$ [21]. DMSO was used to dissolve the compounds and was included in the microplate at $0.5 \%(\mathrm{v} / \mathrm{v})$ to avoid toxicity. Internal controls were also performed with DMSO.

\section{Hemolytic activity}

The hemolytic activity of the isolated ergosterol was evaluated in BALB/c erythrocytes [22]. A 3\% suspension of mouse erythrocytes was incubated for $2 \mathrm{~h}$ with the isolated compound at $100 \mu \mathrm{g} / \mathrm{mL}$ in 96 -well U-shape microplate at $25{ }^{\circ} \mathrm{C}$ and the supernatant was read at $550 \mathrm{~nm}$ in a spectrophotometer FilterMax F5 MultiMode Microplate Reader, Molecular Devices (USA). Ultrapure distilled water was used as a positive control (100\% hemolysis) and phosphate-buffered saline (PBS) as a negative control ( $0 \%$ hemolysis). DMSO was also used at $0.5 \%$ as internal control.

\section{Mechanism of action of ergosterol}

As standard conditions, free trypomastigotes of $T$. cruzi obtained from LLC-MK2 cultures were washed twice and seeded on $2 \times 10^{6} /$ well in PBS to 96-well black polystyrene microplate. The isolated compound was tested at the $\mathrm{IC}_{99}$ value $(100 \mu \mathrm{g} / \mathrm{mL})$ and incubation was performed at $37{ }^{\circ} \mathrm{C}, 5 \% \mathrm{CO}_{2}$. Fluorescence was monitored using FilterMax F5 Multi-Mode Microplate Reader, Molecular Devices (USA) at respective wavelengths. In all mechanism assays, the following internal controls were used in presence of respective dyes (Sytox Green, MitoTracker Red CM-H2XROS or $\mathrm{H}_{2}$ DCf-DA): the background fluorescence of the isolated compound at the respective wavelengths; the possible interference of DMSO; untreated (control) trypomastigotes; and medium without any cells. Samples were tested in 
triplicate and at least three independent assays were performed.

\section{Evaluation of plasma membrane permeability}

Under standard conditions, trypomastigotes were incubated with $1 \mu \mathrm{M}$ Sytox Green for $15 \mathrm{~min}$ at $37{ }^{\circ} \mathrm{C}, 5 \%$ $\mathrm{CO}_{2}$ in the dark [23]. Then, the isolated compound was added at $100 \mu \mathrm{g} / \mathrm{mL}$ and the fluorescence was monitored every $20 \mathrm{~min}$ during $80 \mathrm{~min}$ at excitation $(\lambda$ ex) and emission $(\lambda \mathrm{em})$ wavelengths of 485 and $520 \mathrm{~nm}$, respectively. The maximum membrane permeabilization was obtained with $0.5 \%$ Triton X-100, as a positive control.

\section{Evaluation of the mitochondrial membrane potential}

Under standard conditions, trypomastigotes were incubated with the isolated compound at $100 \mu \mathrm{g} / \mathrm{mL}$ during $60 \mathrm{~min}$ and then MitoTracker Red CM-H2XROS (500 $\mathrm{nM}$ ) was added and incubated for $40 \mathrm{~min}$ in dark. The minimal mitochondrial membrane potential was obtained by treatment of trypomastigotes with $10 \mu \mathrm{M}$ FCCP, a known mitochondrial uncoupler. Trypomastigotes were washed twice with PBS before fluorescence reading at $\lambda e x=540 \mathrm{~nm}$ and $\lambda e x=595 \mathrm{~nm}$ [21].

\section{Detection of reactive oxygen species (ROS)}

Intracellular ROS levels were measured using fluorescent probe $\mathrm{H}_{2}$ DCf-DA. Under standard conditions, except by the use of HBSS solution instead of PBS, trypomastigotes were incubated with the isolated compound ergosterol at $100 \mu \mathrm{g} / \mathrm{mL}$ and sodium azide $(10 \mathrm{mM})$ as a positive control in order to obtain high levels of ROS production during $60 \mathrm{~min}$. Then, fluorescent probe $\mathrm{H}_{2}$ DCf-DA was added ( $\left.5 \mu \mathrm{M}, 15 \mathrm{~min}\right)$ and the fluorescence intensity measured at $\lambda \mathrm{ex}=485 \mathrm{~nm}$ and $\lambda \mathrm{ex}=$ $520 \mathrm{~nm}$ [23].

\section{Statistical analysis}

The $\mathrm{IC}_{50}$ and $\mathrm{CC}_{50}$ values were calculated using sigmoid dose-response curves in GraphPad Prism 5.0 software, and the 95\% confidence intervals are included in parentheses. The ANOVA test was used for significance $p$ value. The data obtained from the mechanism of action represent the mean and standard deviation (SD) of triplicate samples from at least two independent assays.

\section{Results}

Bioguided fractionation and antitrypanosomal activity The three obtained fractions (n-hexane, EtOAc and butanol) were incubated with free trypanosomes during 24 ho and the viability determined by the resazurin assay. All fractions demonstrated anti-trypomastigote activity against the parasite resulting in $100 \%$ of death at the highest concentration of $300 \mu \mathrm{g} / \mathrm{mL}$. The $\mathrm{n}$-hexane, EtOAc and butanol fractions showed $\mathrm{IC}_{50}$ values of $7.9 \mu \mathrm{g} / \mathrm{mL}, 28.0 \mu \mathrm{g} / \mathrm{mL}$ and $58.3 \mu \mathrm{g} / \mathrm{mL}$, respectively (Table 1). The TLC analysis determined a good resolution for the mixture of $n$-hexane:EtOAc $(1: 1, v / v)$ (data not shown). Together, the analytical assays and the antitrypomastigote activity of $n$-hexane fraction guided the subsequent separations, yielding 17 new fractions, which were compiled into ten groups (CPS1-10) based on their chromatographic similarities. The antitrypanosomal activity was detected in a crystallized fraction [namely CPS-3(3)], which resulted in an $\mathrm{IC}_{50}$ value of $51.3 \mu \mathrm{g} /$ $\mathrm{mL}$ (46.1-57.0) against the trypomastigotes (Table 1).

\section{Biological activity of ergosterol}

The viability of trypamastigotes of T. cruzi and mammalian cells treated with ergosterol was determined by resazurin and MTT assay after $48 \mathrm{~h}$ of incubation. Ergosterol showed a moderate anti-trypomastigote activity with $\mathrm{IC}_{50}=51.3 \mu \mathrm{g} / \mathrm{mL}$; benznidazole was used as standard drug and resulted in an $\mathrm{IC}_{50}=4.4 \mu \mathrm{g} / \mathrm{mL}$. Additionally, light microscopy analysis confirmed the lethal effect of ergosterol in trypomastigotes. Ergosterol was also tested against the intracellular amastigotes of $T$. cruzi, but demonstrated no activity. Ergosterol (and benznidazole) showed lack of toxicity to BALB/c peritoneal macrophages to the maximal tested concentration of $200 \mu \mathrm{g} / \mathrm{mL}$ (Table 1). The hemolytic activity of ergosterol was tested in mice erythrocytes, but the compound induced no significant hemolysis $(7.03 \% \pm 11.6)$ to the highest tested concentration (Table 1) when compared to untreated cells.

\section{Ergosterol structural elucidation}

The CPS-3(3) fraction was subjected to ${ }^{1} \mathrm{H}$ and ${ }^{13} \mathrm{C}$ RMN and GC-EI-MS analysis for structural elucidation. ${ }^{13} \mathrm{C}$ RMN spectra reveals $\mathrm{C}_{28}$-sterol ergostane skeleton, including signals of six unsaturated carbonsat $\delta_{\mathrm{C}} 116.3$ -

Table 1 Antitrypanosomal activity of ergosterol and cytotoxicity against mammalian cells

\begin{tabular}{llllll}
\hline Compound & $\mathrm{C}_{50}(\mu \mathrm{g} / \mathrm{mL})$ & $\mathrm{IC}_{50}(\mu \mathrm{g} / \mathrm{mL})$ & $\mathrm{CC}_{50}(\mu \mathrm{g} / \mathrm{mL})$ & Selectivity index & Hemolytic activity $(\mathrm{SD})$ \\
& $95 \% \mathrm{Cl}$ & $95 \% \mathrm{Cl}$ & $95 \% \mathrm{Cl}$ & \\
& trypomastigote & amastigote & macrophages & & \\
\hline Ergosterol & $51.3(46.0-57.0)$ & $>100$ & $>200$ & $>3.9$ & $7.03 \%( \pm 11.6)$ \\
Benznidazole & $4.4(3.7-5.1)$ & $1.9(1.2-2.3)$ & $>200$ & $>45.0$ & nd \\
\hline
\end{tabular}

$\mathrm{IC}_{50}: 50 \%$ effective concentration; $\mathrm{CC}_{50}: 50 \%$ cytotoxic concentration; $95 \% \mathrm{Cl}$ : 95\% confidence interval; $\mathrm{SI}$ : selectivity index calculated as (SI $=\mathrm{CC}_{50}$ mammalian cell/ $\mathrm{IC}_{50}$ trypomastigotes); nd: not determined 
141.4 corresponding to $\mathrm{C}-5\left(\delta_{\mathrm{C}} 139.8\right)$; C-6 $\left(\delta_{\mathrm{C}} 119.6\right)$, $\mathrm{C}-7\left(\delta_{\mathrm{C}} 116.3\right), \mathrm{C}-8\left(\delta_{\mathrm{C}} 141.4\right), \mathrm{C} 22\left(\delta_{\mathrm{C}} 135.6\right)$ and $\mathrm{C} 23$ $\left(\delta_{\mathrm{C}} 131.9\right)$. Methyl carbons were observed in C-18 $\left(\delta_{\mathrm{C}}\right.$ $12.1), \mathrm{C}-19\left(\delta_{\mathrm{C}} 16.3\right), \mathrm{C}-21\left(\delta_{\mathrm{C}} 21.1\right) \mathrm{C}-26\left(\delta_{\mathrm{C}} 28.3\right), \mathrm{C}-$ $27\left(\delta_{C} 19.7\right)$ and $C-28\left(\delta_{C} 17.6\right)$, whereas hydroxyl group was observed in $\mathrm{C}-3\left(\delta_{\mathrm{C}} 70.5\right) .{ }^{1} \mathrm{H}$ RMN corroborated sterol $\Delta^{5,7}$ structure by signals $\delta_{\mathrm{H}} 5.58(d d, \mathrm{~J}=3.0$; $5.5 \mathrm{~Hz})$ and $5.38(d d, \mathrm{~J}=2.9 ; 5.4 \mathrm{~Hz})$ diagnostic for olefin hydrogens $\mathrm{H}-6$ and $\mathrm{H}-7$, besides multiplet in $\delta_{\mathrm{H}} 3.64$ $(\mathrm{H}-3)$ indicate the presence of hydrogen linked to carbinolic carbon. Double bonds were observed at signal 5.20 (m) relative to $\mathrm{H}-22$ and $\mathrm{H}-23$. Still, signals at region $\delta_{\mathrm{H}}$ 0.8 and 1.1 relative to methyl groups identified two singlet hydrogen in $\delta_{\mathrm{H}} 0.95\left(\mathrm{CH}_{3}-\mathrm{C}-18\right)$ and $0.65\left(\mathrm{CH}_{3}-\mathrm{C}\right.$ $19)$, and four duplets in $\delta \mathrm{H} 0.82$ (CH3-27), 0.84 (CH3-26); 0.92 (CH3-28), 1.04 (CH3-21). The assignment of all the carbon signals was performed by comparison with the reported data (Table 2). Table 1 compiles $1 \mathrm{H}$ and 13C RMN comparing with literature $[24,25]$.

GC-EI-MS also confirmed the identity and purity of ergosterol (Fig. 1) by the presence of $\mathrm{m} / \mathrm{z} 396$ corresponding to molecular formula $\mathrm{C}_{28} \mathrm{H}_{44} \mathrm{O}$ and fragments $\mathrm{m} / \mathrm{z} 378\left[\mathrm{M}-\mathrm{H}_{2} \mathrm{O}\right]^{+}, \mathrm{m} / \mathrm{z} 363\left[\mathrm{M}-\mathrm{CH}_{3}-\mathrm{H}_{2} \mathrm{O}\right]^{+}, \mathrm{m} / \mathrm{z} 253$ $\left[\mathrm{M} \text {-side chain- } \mathrm{H}_{2} \mathrm{O}\right]^{+}$and $\mathrm{m} / \mathrm{z} 271[\mathrm{M} \text {-side chain }]^{+}$, a typical fragmentation profile of sterols [26] (Additional file 1).

\section{Permeabilization of plasma membrane}

Ergosterol (at $\mathrm{IC}_{99} 100 \mu \mathrm{g} / \mathrm{mL}$ ) was incubated for 80 min with trypomastigotes and the permeability of plasma membrane was evaluated through the fluorescence of Sytox Green dye $(1 \mu \mathrm{M})$. The entrance of Sytox

Table $2{ }^{13} \mathrm{C}$ and ${ }^{1} \mathrm{H}$ RMN data for ergosterol (75 $\mathrm{MHz}$ and $300 \mathrm{MHz}$ )

\begin{tabular}{|c|c|c|c|c|}
\hline Position & $\delta_{C}$ EXP & $\delta_{C}$ LIT. $^{a}$ & $\delta_{H}$ EXP & $\delta_{H}$ LIT. $^{b}$ \\
\hline 1 & 38.4 & 38.5 & & \\
\hline 2 & 31.9 & 32.1 & & \\
\hline 3 & 70.5 & 70.5 & $3.64 \mathrm{~m}(1 \mathrm{H})$ & $3.61 \mathrm{~m} \mathrm{(1H)}$ \\
\hline 4 & 40.8 & 40.9 & & \\
\hline 5 & 139.8 & 139.8 & & \\
\hline 6 & 119.6 & 119.7 & $5.58 \mathrm{dd}(5.5,3.0 \mathrm{~Hz}, 1 \mathrm{H})$ & $5.56 \mathrm{dd}(5.4,2.2 \mathrm{~Hz}, 1 \mathrm{H})$ \\
\hline 7 & 116.3 & 116.4 & $5.38 \mathrm{dd}(5.4,2.9 \mathrm{~Hz}, 1 \mathrm{H})$ & $5.38 \mathrm{dd}(5.4,2.5 \mathrm{~Hz}, 1 \mathrm{H})$ \\
\hline 8 & 141.4 & 141.3 & & \\
\hline 9 & 46.2 & 42.3 & & \\
\hline 10 & 37.1 & 37.1 & & \\
\hline 11 & 21.1 & 21.1 & & \\
\hline 12 & 39.1 & 39.1 & & \\
\hline 13 & 42.9 & 42.9 & & \\
\hline 14 & 54.6 & 54.6 & & \\
\hline 15 & 22.9 & 23.1 & & \\
\hline 16 & 28.3 & 28.3 & & \\
\hline 17 & 55.7 & 55.8 & & \\
\hline 18 & 12.1 & 12.1 & $0.95 \mathrm{~s}(3 \mathrm{H})$ & $0.95 \mathrm{~s}(3 \mathrm{H})$ \\
\hline 19 & 16.3 & 16.3 & $0.65 \mathrm{~s}(3 \mathrm{H})$ & $0.63 \mathrm{~s}(3 \mathrm{H})$ \\
\hline 20 & 40.3 & 40.4 & & \\
\hline 21 & 21.1 & 21.2 & $1.04 \mathrm{~d}(\mathrm{~J}=6.6 \mathrm{~Hz}, 3 \mathrm{H})$ & $1.00 \mathrm{~d}(\mathrm{~J}=6.6 \mathrm{~Hz}, 3 \mathrm{H})$ \\
\hline 22 & 135.6 & 135.6 & $5.20 \mathrm{~m}(1 \mathrm{H})$ & $5.20 \mathrm{~m}(1 \mathrm{H})$ \\
\hline 23 & 131.9 & 132.1 & $5.21 \mathrm{~m} \mathrm{(1H)}$ & $5.20 \mathrm{~m}(1 \mathrm{H})$ \\
\hline 24 & 42.9 & 42.9 & & \\
\hline 25 & 33.1 & 33.1 & & \\
\hline 26 & 19.9 & 20.0 & $0.84 \mathrm{~d}(\mathrm{~J}=6.7 \mathrm{~Hz}, 3 \mathrm{H})$ & $0.84 \mathrm{~d}(J=6.7 \mathrm{~Hz}, 3 \mathrm{H})$ \\
\hline 27 & 19.7 & 19.7 & $0.82 \mathrm{~d}(\mathrm{~J}=6.7 \mathrm{~Hz}, 3 \mathrm{H})$ & $0.83 \mathrm{~d}(\mathrm{~J}=6.7 \mathrm{~Hz}, 3 \mathrm{H})$ \\
\hline 28 & 17.6 & 17.6 & $0.92 \mathrm{~d}(J=6.6 \mathrm{~Hz}, 3 \mathrm{H})$ & $0.95 \mathrm{~d}(3 \mathrm{H})$ \\
\hline
\end{tabular}




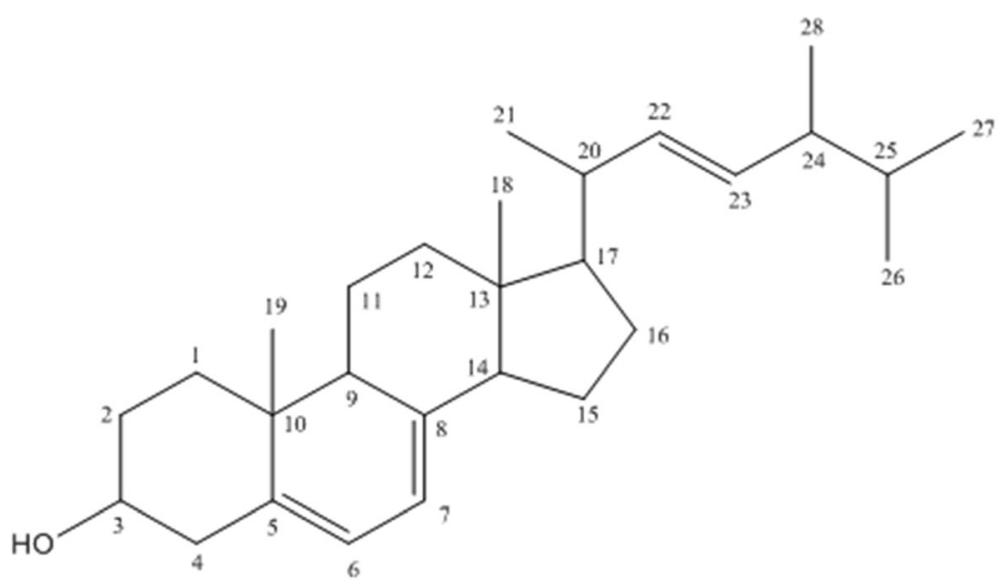

Fig. 1 Structure of ergosterol confirmed by ${ }^{13} \mathrm{C},{ }^{1} \mathrm{H}$ RMN and GC-El-MS

Green dye is allowed solely in injured plasma membrane, otherwise, its influx is precluded and no fluorescence can be measured. The increase of the dye caused by ergosterol (Fig. 2) were significant $(p<0.002)$ compared to untreated parasites, suggesting the alteration of the plasma membrane permeability when compared to the positive control with $0.5 \% \operatorname{Tx} 100(p<0.001)$, a non-ionic detergent (Fig. 2).

\section{Alteration of mitochondrial membrane potential}

Alteration in mitochondrial membrane potential was determined by the fluorescence of Mitotracker Red CM$\mathrm{H}_{2}$ XROS dye (500 nM) in trypomastigotes treated with ergosterol $(100 \mu \mathrm{g} / \mathrm{mL})$ for $60 \mathrm{~min}$. Ergosterol treatment caused significant decreased in the accumulation of Mitotracker Red at mitochondria indicating an effect of depolarization since normal potential guided maximal accumulation of dye in untreated trypomastigotes (control). Mitochondrial dysfunction promoted by ergosterol was comparable to that achieved by the treatment with $10 \mu \mathrm{M}$ FCCP (Fig. 3).

\section{Reactive oxygen species (ROS) production}

The production of ROS in trypomastigotes incubated with ergosterol (60 min, $100 \mu \mathrm{g} / \mathrm{mL}$ ) was evaluated by the fluorescence of $\mathrm{H}_{2} \mathrm{DCF}-\mathrm{DA}$ dye $(5 \mu \mathrm{M})$. Trypomastigotes treated with ergosterol showed no significant increase in the production of ROS, showing levels similar to the untreated parasites. Trypomastigotes treated with sodium azide $(10 \mathrm{mM})$ showed intense fluorescence as a positive control (Fig. 4).

\section{Discussion}

Natural secondary metabolites isolated from basidiomycetes have been described as rich source of bioactive molecules. Terpenoids isolated from Lentinus strigosus and lanostane-type triterpenes isolated from Astraeus hygrometricus are some examples of compounds with

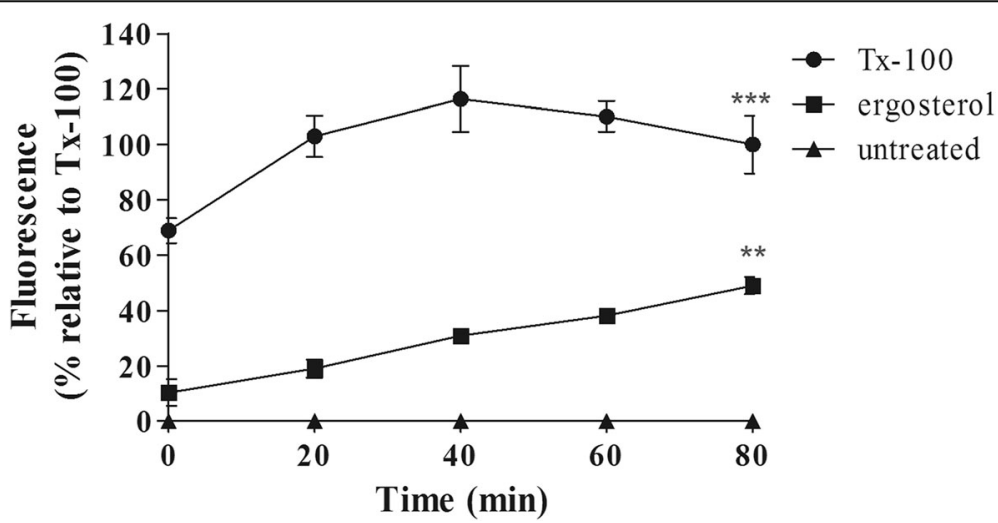

Fig. 2 Effect of ergosterol on plasma membrane permeabilization of trypomastigotes of $T$. cruzi. Sytox Green $(1 \mu M)$ fluorescence was measured spectrofluorimetrically every $20 \mathrm{~min}$. Minimum and maximum permeabilization were obtained by non-treatment and Tx-100 0.5\%, respectively. Fluorescence was quantified by calculating the mean percentages of untreated $(0 \%)$ and Tx-100-treated (100\%) trypomastigotes. ${ }^{* * *} p<0.001$ and ${ }^{* *} p<0.002$. A representative assay is shown 


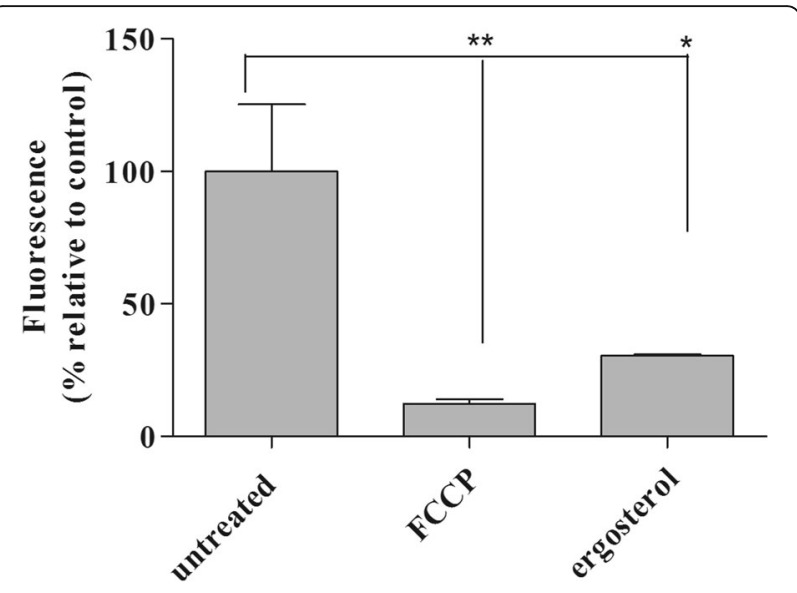

Fig. 3 Effect of ergosterol in the mitochondrial function of trypomastigotes. Fluorescence of Mitotracker Red $\mathrm{CM}-\mathrm{H} 2 \mathrm{XROS}$ dye (500 nM) was spectrofluorimetrically measured after $60 \mathrm{~min}$ of incubation. Maximal and minimal fluorescence was achieved by non- or FCCP $(10 \mu \mathrm{M})$ treatments, respectively. Fluorescence was quantified by calculating the mean percentage of untreated parasites (100\%). ${ }^{*} p<0.001$. A representative assay is shown

promising activity against protozoan parasites such as $T$. cruzi and Leishmania [9, 24, 27].

Few studies on the chemical composition of mushrooms Pleurotus salmoneostramineus have been performed whereas the evaluation of their biological activities remains underexplored $[15,28,29]$. In the present study, the fractionating of the organic crude extract of $P$. salmoneostramineus yielded an antitrypanosomal substance. Our initial data demonstrated the presence of antiparasitic compounds in fractions of different polarities, such as $n$-hexane, EtOAc and butanol, which suggests that no single compound exists with efficacy

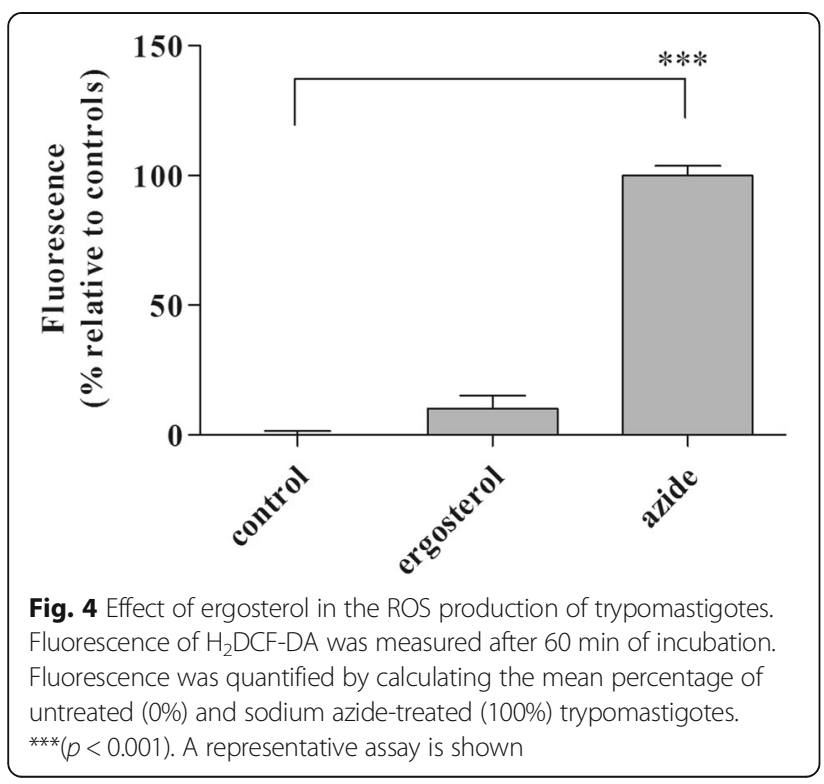

against T. cruzi parasites. Among them, the ergosterol was isolated in large amount as a crystalized pure substance further elucidated by NMR and GC-EI-MS based in the literature data [24-26].

Ergosterol is the major sterol that composes membranes of $T$. cruzi parasites - including plasma, inner mitochondrial and glycosomal membranes - instead of cholesterol, its counterpart in mammalian cells that is usually confined to the plasma membrane [30-32]. Trypanosoma cruzi normally synthesizes sterols and occasionally leucine from carbon precursors [33]. The singularity of the sterol composition of $T$. cruzi parasites - closest to fungi cells than to mammalian host cells has validated SBP as target for new therapeutic drugs [34]. Indeed, T. cruzi CPY51 (TcCPY51) inhibitors posaconazole and ravuconazole - entered in Drugs for Neglected Diseases Initiative (DNDi) clinical trials for Chagas disease despite the clinical failure recently reported $[35,36]$. In general, the efficacy of TcCYP51 inhibitor has been considerably variable depending on the parasite strain and time of exposure [36, 37].

In addition to TcCYP51 inhibitors, sterols isolated from different natural sources including plants, marine sponges and amphibians have demonstrated to present antiprotozoan activities. Interestingly, ergosterol itself can be trypanocidal at unusual levels from its natural metabolism [22, 38, 39]. For example, T. cruzi amastigotes had $94 \%$ of growth inhibited by $10 \mu \mathrm{M}$ of ergosterol [40]. A previous study demonstrated that ergosterol peroxide, but not ergosterol, isolated from the basidiomycete Pleurotus ostreatus also presented anti-T. cruzi activity, with an $\mathrm{IC}_{50}$ value of $6.7 \mu \mathrm{g} / \mathrm{mL}$ against the insect form, epimastigotes [10]. When compared to our results, the previous work suggests that ergosterol peroxide is approximately 8 -fold more active than ergosterol against trypomastigote forms. This could be due to the presence of the endoperoxide group, a known structure presenting potential biological properties [41, 42].

Additionally, differences may rely on metabolic specificities among forms of T. cruzi. For example, extracellular epimastigotes found in the insect vector have been described to be more susceptible to drugs than trypomastigotes, a parasite form found inside cells and bloodstream of vertebrate hosts [43]. Relapse and therapeutic failure have been described to arise from resident trypomastigotes, usually not affected by conventional therapy, which preferentially target intracellular amastigotes [44]. This information highlight the importance of selecting new anti-trypomastigote compounds.

The lethal action of ergosterol against trypomastigotes of $T$. cruzi was investigated. Ergosterol-treated trypomastigotes showed a rapid plasma membrane permeabilization as determined by the Sytox Green fluorescence. Alterations in plasma membrane composition are known to 
modify fluidity and cellular morphology. For example, high concentrations of ergosterol have been speculated to be associated with rigidity, whereas low concentrations cause disorganization/disruption of the plasma membrane [45-47]. In our work, the physicochemical properties of ergosterol may have contributed to its crossing through plasma membrane, thus rapidly altering the permeability by disturbing normal lipid composition and modifying its fluidity and permeability. Disturbances of plasma membrane permeability largely contribute to trypomastigote death. Numerous metabolites from natural origin including soulamarin, dermaseptins and phylloseptins have been reported to trigger such death mechanism [20, 23]. Moreover, drugs in clinical use for leishmaniasis such as miltefosine and amphotericin $\mathrm{B}$ are known to alter the permeability of plasma membrane $[48,49]$. In this study, T. cruzi trypomastigotes treated with ergosterol suffered a rapid depolarization of the mitochondrial membrane potential probably by a direct accumulation in the mitochondria or as a secondary effect of the disturbance in plasma membrane permeability. Corroborating the previous hypothesis, exogenous ergosterol, but not cholesterol, is capable of abolishing the ketoconazole-induced massive swelling of the mitochondria [50].

Under conditions of permeability disturbance and loss of mitochondrial potential, the single mitochondria of $T$. cruzi may produce excessive ROS [51-53]. Our results demonstrated that ergosterol-treated trypomastigotes did not present significant alteration in ROS levels. These data suggest that exogenous supplementation of ergosterol may target the mitochondria and act as ROS scavengers, as indicated by a recent finding reported elsewhere [46]. Additionally, Leishmania (Leishmania) donovani parasites that are CYP51-defective constitutively present low ergosterol levels and higher susceptibility to oxidative stress induced by antimony [54]. The cell viability is increased during exposure to antimony by in vitro supplementation of ergosterol [45]. Therefore, we suggest that oxidative stress may not be contribute to the mechanism of action of ergosterol in $T$. cruzi parasites.

\section{Conclusion}

The basidiomycete mushroom Pleurotus salmoneostramineus demonstrated to be an interesting and underexplored natural source for antiparasitic metabolites. Disturbances in the permeability of plasma membrane and loss of mitochondrial membrane potential without involvement of oxidative stress were pointed as initial mechanisms of action of ergosterol against T. cruzi. Although ergosterol is a constituent of the plasma membrane of $T$. cruzi, it is also effective to eliminate the parasite. The compound is a low cytotoxic substance that may be useful as scaffold for future synthesis of new derivatives against Trypanosoma cruzi.

\section{Additional file}

Additional file 1: Ergosterol fragmentation proposal interpreted from GM-El-MS analysis. (DOCX $31 \mathrm{~kb}$ )

\begin{abstract}
Abbreviations
ACD: Acute Chagas disease; CC: Column chromatography; CC $_{50}: 50 \%$ cytotoxic concentration; CD: Chagas disease; CPS: Column Pleurotus salmoneostramineus; DMSO: Dimethyl sulfoxide; DNDi: Drugs for Neglected Diseases Initiative; EtOAc: Ethyl acetate; FBS: Fetal bovine serum; HBSS: Hank's Balanced Salt Solution; IC 50 : 50\% inhibitory concentration; PBS: Phosphatebuffered saline; ROS: Reactive oxygen species; RPMI: Roswell Park Memorial Institute Medium; SBP: Sterol biosynthetic pathway; SDS: Sodium dodecyl sulfate; TCCPY51: T. cruzi CPY51; TLC: Thin layer chromatography
\end{abstract}

\section{Funding}

This work was supported by grants from São Paulo State Research Foundation (FAPESP 2013/50228-8, 2016/24985-4) and scholarships from CAPES.

\section{Availability of data and materials}

All data generated or analyzed during this study are included in this article and its Additional file 1.

\section{Authors' contributions}

TRA, JTM, MLL, MKG and MAN performed the research and analyzed data. DCP and PS performed NMR and GC-MS analysis. MLL, MKG and AGT wrote the manuscript. AGT and DCP designed the study. All authors read and approved the final manuscript.

\section{Competing interests}

The authors declare that they have no competing interests.

Consent for publication

Not applicable.

\section{Ethics approval and consent to participate}

Animal procedures were approved by the Research Ethics Commission of Adolfo Lutz Institute (CEUA-IAL-Pasteur 01/2011) and were in agreement with the Guide for the Care and Use of Laboratory Animals from the National Academy of Sciences.

\section{Publisher's Note}

Springer Nature remains neutral with regard to jurisdictional claims in published maps and institutional affiliations.

\section{Author details}

${ }^{1}$ Center for Parasitology and Mycology, Instituto Adolfo Lutz, Avenida Dr. Arnaldo, 351, $8^{\circ}$ andar, CEP 01246-000, São Paulo, SP, Brazil. ${ }^{2}$ Institute of Tropical Medicine of São Paulo, University of São Paulo (USP), São Paulo, SP, Brazil. ${ }^{3}$ Institute of Environmental, Chemical and Pharmaceutical Sciences, Federal University of São Paulo, São Paulo (UNIFESP), Diadema, SP, Brazil.

${ }^{4}$ Laboratory of Biochemistry and Biophysics, Butantan Institute, São Paulo, SP, Brazil.

Received: 3 February 2017 Accepted: 19 May 2017

Published online: 30 May 2017

References

1. Bestetti RB, Cardinalli-Neto A. Did death hinder the process of justice? Carlos Chagas and the Nobel Prize of 1935. Int J Cardiol. 2011;147(1):172-3.

2. WHO. World Health Organization. Chagas disease. http://www.who.int/ chagas/en/. Accessed 14 Jan 2017.

3. Pereira PCM, Navarro EC. Challenges and perspectives of Chagas disease: a review. J Venom Anim Toxins incl Trop Dis. 2013;19(1):34.

4. de Góes CE, Dos Santos SO, Sojo-Milano M, Amador EC, Tatto E, Souza DS, et al. Acute Chagas disease in the Brazilian Amazon: epidemiological and clinical features. Int J Cardiol. 2017;235:176-8. 
5. De Souza W. Trypanosoma cruzi-host cell interaction. Front Immunol. 2014;5: 339.

6. Boscardin SB, Torrecilhas AC, Manarin R, Revelli S, Rey EG, Tonelli RR, et al. Chagas' disease: an update on immune mechanisms and therapeutic strategies. J Cell Mol Med. 2010;14(6B):1373-84.

7. Croft SL, Barrett MP, Urbina JA. Chemotherapy of trypanosomiases and leishmaniasis. Trends Parasitol. 2005;21(11):508-12.

8. Romanha AJ, Castro SL, de Soeiro MN, Lannes-Vieira J, Ribeiro I, Talvani A, et al. In vitro and in vivo experimental models for drug screening and development for Chagas disease. Mem Inst Oswaldo Cruz. 2010;105(2): 233-8.

9. Souza-Fagundes EM, Cota BB, Rosa LH, Romanha AJ, Corrêa-Oliveira R, Rosa CA, et al. In vitro activity of hypnophilin from Lentinus strigosus: a potential prototype for Chagas disease and leishmaniasis chemotherapy. Braz J Med Biol Res. 2010;43(11):1054-61.

10. Ramos-Ligonio A, López-Monteon A, Trigos A. Trypanocidal activity of ergosterol peroxide from Pleurotus ostreatus. Phytother Res. 2012;26(6): 938-43.

11. Borges GM, De Barba FFM, Schiebelbein AP, Pereira BP, Chaves MB, Silveira $M L L$, et al. Extracellular polysaccharide production by a strain of Pleurotus djamor isolated in the south of Brazil and antitumor activity on sarcoma 180. Braz J Microbiol. 2013;44(4):1059-65.

12. Rosa LH, Machado KM, Rabello AL, Souza-Fagundes EM, Correa-Oliveira R, Rosa CA, et al. Cytotoxic, immunosuppressive, trypanocidal and antileishmanial activities of Basidiomycota fungi present in Atlantic rainforest in Brazil. Antonie Van Leeuwenhoek. 2009;95(3):227-37.

13. Chowdhury MMH, Kubra K, Ahmed SR. Screening of antimicrobial, antioxidant properties and bioactive compounds of some edible mushrooms cultivated in Bangladesh. Ann Clin Microbiol Antimicrob. 2015;14:8

14. Elsayed EA, El Enshasy H, Wadaan MA, Aziz R. Mushrooms: a potential natural source of anti-inflammatory compounds for medical applications. Mediators Inflamm. 2014;2014:805841

15. Usami A, Nakaya S, Nakahashi H, Miyazawa M. Chemical composition and aroma evaluation of volatile oils from edible mushrooms (Pleurotus salmoneostramineus and Pleurotus sajor-caju). J Oleo Sci. 2014;63(12): 1323-32.

16. Wu X, Zheng $\mathrm{S}$, Cui L, Wang $\mathrm{H}, \mathrm{Ng}$ TB. Isolation and characterization of a novel ribonuclease from the pink oyster mushroom Pleurotus djamor. J Gen Appl Microbiol. 2010;56(3):231-9.

17. Bettiol E, Samanovic M, Murkin AS, Raper J, Buckner F, Rodriguez A. Identification of three classes of heteroaromatic compounds with activity against intracellular Trypanosoma cruzi by chemical library screening. PLoS Negl Trop Dis. 2009;3(2):e384.

18. Mikus J, Steverding D. A simple colorimetric method to screen drug cytotoxicity against Leishmania using the dye Alamar Blue. Parasitol Int. 2000;48(3):265-9.

19. Simões-Silva MR, Nefertiti AS, De Araújo JS, Batista MM, Da Silva PB, Bahia MT, et al. Phenotypic screening in vitro of novel aromatic amidines against Trypanosoma cruzi. Antimicrob Agents Chemother. 2016;60(8):4701-7.

20. Ramírez-Macías I, Marín C, Chahboun R, Messouri I, Olmo F, Rosales MJ, et al. In vitro and in vivo studies of the trypanocidal activity of four terpenoid derivatives against Trypanosoma cruzi. Am J Trop Med Hyg. 2012;87(3):481-8.

21. Pinto EG, Antoniazzi MM, Jared C, Tempone AG. Antileishmanial and antitrypanosomal activity of the cutaneous secretion of Siphonops annulatus. J Venom Anim Toxins incl Trop Dis. 2014;20:50.

22. Tempone AG, Pimenta DC, Lebrun I, Sartorelli P, Taniwaki NN, de Andrade Jr HF, et al. Antileishmanial and antitrypanosomal activity of bufadienolides isolated from the toad Rhinella jimi parotoid macrogland secretion. Toxicon. 2008:52(1):13-21.

23. Rea A, Tempone AG, Pinto EG, Mesquita JT, Rodrigues E, Silva LG, et al. Soulamarin isolated from Calophyllum brasiliense (Clusiaceae) induces plasma membrane permeabilization of Trypanosoma cruzi and mytochondrial dysfunction. PLoS Negl Trop Dis. 2013;7(12):e2556.

24. Wright JLC. The occurrence of ergosterol and (22E,24R)-24-ethylcholesta$5,7,22$-trien-3ß-ol in the unicellular chlorophyte Dunaliella tertiolecta. Can J Chem. 1979:57(19):2569-71.

25. Barrero AF, Oltra JE, Poyatos JA, Jiménez D, Oliver E. Phycomysterols and other sterols from the fungus Phycomyces blakesleeanus. J Nat Prod. 1998; 61(12):1491-6.
26. Galli G, Maroni S. Mass spectrometric investigations of some unsaturated sterols biosynthetically related to cholesterol. Steroids. 1967;10(3):189-97.

27. Lai TK, Biswas G, Chatterjee S, Dutta A, Pal C, Banerji J, et al. Leishmanicidal and anticandidal activity of constituents of Indian edible mushroom Astraeus hygrometricus. Chem Biodivers. 2012;9(8):1517-24.

28. Lo YC, Lin SY, Ulziijargal E, Chen SY, Chien RC, Tzou YJ, et al. Comparative study of contents of several bioactive components in fruiting bodies and mycelia of culinary-medicinal mushrooms. Int J Med Mushrooms. 2012;14(4): $357-63$.

29. Yoon KN, Alam N, Shim MJ, Lee TS. Hypolipidemic and antiatherogenesis effect of culinary-medicinal pink oyster mushroom, Pleurotus salmoneostramineus L. Vass. (higher Basidiomycetes), in hypercholesterolemic rats. Int J Med Mushrooms. 2012;14(1):27-36.

30. Rodrigues CO, Catisti R, Uyemura SA, Vercesi AE, Lira R, Rodriguez C, et al. The sterol composition of Trypanosoma cruzi changes after growth in different culture media and results in different sensitivity to digitoninpermeabilization. J Eukaryot Microbiol. 2001;48(5):588-94.

31. Roberts CW, McLeod R, Rice DW, Ginger M, Chance ML, Goad LJ. Fatty acid and sterol metabolism: potential antimicrobial targets in apicomplexan and trypanosomatid parasitic protozoa. Mol Biochem Parasitol. 2003;126(2):129-42.

32. Quiñones W, Urbina JA, Dubourdieu M, Luis CJ. The glycosome membrane of Trypanosoma cruzi epimastigotes: protein and lipid composition. Exp Parasitol. 2004; 106(3-4):135-49.

33. Ginger ML, Prescott MC, Reynolds DG, Chance ML, Goad LJ. Utilization of leucine and acetate as carbon sources for sterol and fatty acid biosynthesis by Old and New World Leishmania species, Endotypanum monterogeii and Trypanosoma cruzi. Eur J Biochem. 2000;267(9):2555-66.

34. Duschak VG, Couto AS. An insight on targets and patented drugs for chemotherapy of Chagas disease. Recent Pat Antiinfect Drug Discov. 2007; 2(1):19-51.

35. de Soeiro MN, de Souza EM, da Silva CF, da Batista DG, Batista MM, Pavão $\mathrm{BP}$, et al. In vitro and in vivo studies of the antiparasitic activity of sterol 14a-demethylase (CYP51) inhibitor VNI against drug-resistant strains of Trypanosoma cruzi. Antimicrob Agents Chemother. 2013;57(9): 4151-63.

36. Moraes CB, Giardini MA, Kim H, Franco CH, Araujo-Junior AM, Schenkman S, et al. Nitroheterocyclic compounds are more efficacious than CYP51 inhibitors against Trypanosoma cruzi: implications for Chagas disease drug discovery and development. Sci Rep. 2014;4:4703.

37. Francisco AF, Lewis MD, Jayawardhana S, Taylor MC, Chatelain E, Kelly JM. Limited ability of posaconazole to cure both acute and chronic Trypanosoma cruzi infections revealed by highly sensitive in vivo imaging. Antimicrob Agents Chemother. 2015;59(8):4653-61.

38. Nganso YOD, Ngantchou IEW, Nkwenoua E, Nyasse B, Denier C, Hannert V, et al. Antitrypanosomal and cytotoxic activities of 22-Hydroxyclerosterol, a new sterol from Allexis cauliflora (Violaceae). Sci Pharm. 2011;79(1):137-44.

39. Viegelmann C, Parker J, Ooi T, Clements C, Abbott G, Young L, et al. Isolation and identification of antitrypanosomal and antimycobacterial active steroids from the sponge Haliclona simulans. Mar Drugs. 2014;12(5): 2937-52.

40. Planer JD, Hulverson MA, Arif JA, Ranade RM, Don R, Buckner FS. Synergy testing of FDA-approved drugs identifies potent drug combinations against Trypanosoma cruzi. PLoS Negl Trop Dis. 2014;8(7):e2977.

41. Mercer AE, Maggs JL, Sun XM, Cohen GM, Chadwick J, O'Neill PM, et al. Evidence for the involvement of carbon-centered radicals in the induction of apoptotic cell death by artemisinin compounds. J Biol Chem. 2007; 282(13):9372-82.

42. Meshnick SR. Artemisinin: mechanisms of action, resistance and toxicity. Int J Parasitol. 2002;32(13):1655-60.

43. de-Castro SL, Soeiro MN, Higashi KO, Meirelles MN. Differential effect of amphotericin B on the three evolutive stages of Trypanosoma cruzi and on the host cell-parasite interaction. Braz J Med Biol Res. 1993;26(11):1219-29.

44. Chatelain E, Konar N. Translational challenges of animal models in Chagas disease drug development: a review. Drug Des Devel Ther. 2015;9:4807-23.

45. Mathur R, Das RP, Ranjan A, Shaha C. Elevated ergosterol protects Leishmania parasites against antimony-generated stress. FASEB J. 2015; 29(10):4201-13.

46. Braga MV, Urbina JA, de Souza W. Effects of squalene synthase inhibitors on the growth and ultrastructure of Trypanosoma cruzi. Int J Antimicrob Agents. 2004;24(1):72-8. 
47. Lazardi K, Urbina JA, de Souza W. Ultrastructural alterations induced by two ergosterol biosynthesis inhibitors, ketoconazole and terbinafine, on epimastigotes and amastigotes of Trypanosoma (Schizotrypanum) cruzi. Antimicrob Agents Chemother. 1990;34(11):2097-105.

48. Brilhante RS, Caetano EP, Lima RA, Castelo Branco DS, Serpa R, Oliveira JS, et al. In vitro antifungal activity of miltefosine and levamisole: their impact on ergosterol biosynthesis and cell permeability of dimorphic fungi. J Appl Microbiol. 2015;119(4):962-9.

49. Yang TS, Ou KL, Peng PW, Liou BC, Wang WT, Huang YC, et al. Quantifying membrane permeability of amphotericin B ion channels in single living cells. Biochim Biophys Acta. 2013;1828(8):1794-801.

50. Urbina JA, Lazardi K, Aguirre T, Piras MM, Piras R. Antiproliferative effects and mechanism of action of $\mathrm{ICI} 195,739$, a novel bis-triazole derivative, on epimastigotes and amastigotes of Trypanosoma (Schizotrypanum) cruzi. Antimicrob Agents Chemother. 1991;35(4):730-5.

51. Menna-Barreto RF, de Castro SL. The double-edged sword in pathogenic trypanosomatids: the pivotal role of mitochondria in oxidative stress and bioenergetics. Biomed Res Int. 2014;2014:Article ID 614014.

52. Lazarin-Bidóia D, Desoti VC, Ueda-Nakamura T, Dias Filho BP, Nakamura CV Silva SO. Further evidence of the trypanocidal action of eupomatenoid-5: confirmation of involvement of reactive oxygen species and mitochondria owing to a reduction in trypanothione reductase activity. Free Radic Biol Med. 2013;60:17-28.

53. Santos MF, Harper PM, Williams DE, Mesquita JT, Pinto É, da Costa-Silva TA, et al. Anti-parasitic guanidine and pyrimidine alkaloids from the marine sponge Monanchora arbuscula. J Nat Prod. 2015;78(5):1101-12.

54. Verma S, Mehta A, Shaha C. CYP5122A1, a novel cytochrome P450 is essential for survival of Leishmania donovani. PLoS One. 2011;6(9):e25273.

\section{Submit your next manuscript to BioMed Central and we will help you at every step:}

- We accept pre-submission inquiries

- Our selector tool helps you to find the most relevant journal

- We provide round the clock customer support

- Convenient online submission

- Thorough peer review

- Inclusion in PubMed and all major indexing services

- Maximum visibility for your research

Submit your manuscript at www.biomedcentral.com/submit 